УДК 663.1

\title{
INTENSIFICATION OF PROCESSES \\ OF ANAEROBIC FERMENTATION AND UTILIZATION OF BIOLOGICAL HEAT
}

\author{
A. Sokolenko, O. Shevchenko, I. Maksymenko, K. Vasylkivsky \\ National University of Food Technologies
}

\begin{tabular}{|c|c|}
\hline Key words: & ABSTRACT \\
\hline $\begin{array}{l}\text { Heat } \\
\text { Anaerobic fermentation } \\
\text { Intensification } \\
\text { Utilization } \\
\text { Osmotic pressure } \\
\text { Hydrostatic pressure } \\
\text { Ethyl alcohol } \\
\text { Solubility } \\
\text { Henry's law }\end{array}$ & $\begin{array}{l}\text { The article deals with the peculiarities of the flow and } \\
\text { possibilities of intensification of processes of anaerobic fer- } \\
\text { mentation and utilization of their thermal resources. The } \\
\text { purpose of the study is defined as the search for conditions } \\
\text { and the implementation of the hardware support of the latest } \\
\text { proposals. The article shows the limitations concerning the } \\
\text { osmotic pressures of solutions of } \mathrm{C}_{2} \mathrm{~N}_{5} \mathrm{OH} \text { and } \mathrm{CO}_{2} \text {, and the } \\
\text { possibilities of limiting their effects, taking into account the } \\
\text { experience of brewers in the technologies of production of }\end{array}$ \\
\hline $\begin{array}{l}\quad \text { Article history: } \\
\text { Received } 16.05 .2018 \\
\text { Received in revised form } \\
29.05 .2018 \\
\text { Accepted } 15.06 .2018\end{array}$ & $\begin{array}{l}\text { non-alcoholic beer, are estimated. Measures for the creation } \\
\text { of local zones in the media of saturated, unsaturated and } \\
\text { saturated with } \mathrm{CO}_{2} \text { fermentation vehicles are proposed. The } \\
\text { existence of such zones can be artificially strengthened and } \\
\text { used to intensify mass and energy exchanges. }\end{array}$ \\
\hline $\begin{array}{l}\text { Corresponding author: } \\
\text { A. Sokolenko } \\
\text { E-mail: } \\
\text { npnuht@ukr.net }\end{array}$ & $\begin{array}{l}\text { It is proposed to use the development of the utilization of } \\
\text { biological heat of fermentation based on the use of heat } \\
\text { pumps with a combination of fermentation and distillation } \\
\text { technologies. Information is given on the limitations of the } \\
\text { combination in one process of fermentation and vacuum } \\
\text { distillation due to hydrostatic pressures. }\end{array}$ \\
\hline
\end{tabular}

DOI: $10.24263 / 2225-2924-2018-24-3-17$

\section{ІНТЕНСИФІКАЦІЯ ПРОЦЕСІВ АНАЕРОБНОГО БРОДІННЯ ТА УТИЛІЗАЦІЯ БІОЛОГІЧНОЇ ТЕПЛОТИ}

\author{
А.І. Соколенко, О.Ю. Шевченко, І.Ф. Максименко, К.В. Васильківський \\ Національний університет харчових технологій
}

У статті досліджено особливості перебігу та можливості інтенсифікаиії прочесів анаеробного бродіння й утилізації їх теплових ресурсів. Мета дослідження визначена як пошук умов і реалізачії апаратурного забезпечення новітніх пропозицій. Показано граничні обмеження, щзо стосуються осмотичних тисків розчинів $\mathrm{C}_{2} \mathrm{H}_{5} \mathrm{OH}$ i $\mathrm{CO}_{2}$, очінено можливості обмежень $\ddot{x}$ виливів з урахуванням досвіду пивоварів у технологіях виробництва безалкогольного пива. Запропоновано заходи щодо створення локальних зон у середовищах бродильних апаратів насичених, ненасичених і перенасичених на $\mathrm{CO}_{2}$. 
Існування таких зон може штучно підсилюватись і використовуватись для інтенсифікаиії масо- $і$ енергообміну.

Запропоновано до використання розробки щодо утилізачії біологічної теплоти бродіння на основі використання теплових насосів з поєднанням у паралельних технологіях бродіння і перегонки. Наведено інформаиію, що стосується обмежень поєднання в одному прочесі бродіння $і$ вакуумної перегонки узв'язку з гідростатичними тисками.

Ключові слова: теплота, анаеробне бродіння, інтенсифікація, утилізація, осмотичний тиск, гідростатичний тиск, спирт, розчинність, закон Генрі.

Постановка проблеми. До числа важливих у технології виробництва етилового спирту завдань відносять підвищення граничних значень концентрацій розчиненого $\mathrm{C}_{2} \mathrm{H}_{5} \mathrm{OH}$, оскільки останне пов'язано з продуктивністю технологічного обладнання, інтенсивністю процесів анаеробного бродіння й енергетичними витратами на процес перегонки [1].

Очевидно, що перші дві вимоги між собою взаємопов'язані і стосуються кількох чинників, до числа яких відносяться термодинамічні параметри середовища, його гідродинамічні показники, властивості мікроорганізмів тощо. Названі параметри стосуються як перехідних процесів у середовищах, так $\mathrm{i}$ усталених режимів. Важливо, що процеси анаеробного бродіння відбуваються за неперервної зміни складу та концентрацій розчинених речовин i мікроорганізмів. 3 деякою мірою умовності ці зміни узагальнюються показниками осмотичних тисків [3; 4], які відносять на синтезовані в середовищах спирт і діоксид вуглецю. За близьких молекулярних мас $\mathrm{C}_{2} \mathrm{H}_{5} \mathrm{OH}$ i $\mathrm{CO}_{2}$ осмотичний тиск етилового спирту переважає у зв'язку з його збільшеною концентрацією порівняно 3 концентрацією діоксиду вуглецю, яка лімітується законом Генрі. Саме концентрація спирту $8 . . .10 \%$ масових $є$ критичною i такою, що спричиняє бактеріостатичні ефекти мікроорганізмів. Окрім того, вона лімітує питому продуктивність бродильних апаратів і приводить до підвищених енергетичних витрат в процесах перегонки $[4 ; 5]$.

Наступним вагомим недоліком процесів анаеробного бродіння $\epsilon$ доведення зброджуваних середовищ до станів насичення на $\mathrm{CO}_{2}$, що обов'язково досягаються і створюють потужний опір масопередачі на межі поділу фаз «мікроорганізми - середовище».

3 огляду на вищевикладене можна стверджувати, що:

- активація процесів анаеробного бродіння в газорідинних середовищах можлива за рахунок їх гідродинамічних режимів, що супроводжуватиметься підвищенням пропускної здатності системи;

- обмеження енергетичних витрат першоджерел на процеси перегонки слід здійснювати на шляху використання біологічної теплоти бродіння;

- заслуговує на увагу оцінка досвіду виробників безалкогольного пива 3 вилучення 3 напоїв етилового спирту.

Мета дослідження: пошук умов та розробка пропозицій щодо удосконалення технологій і апаратурного забезпечення анаеробного зброджування середовищ з використанням біологічної теплоти бродіння. 
Методи дослідження. Феноменологічний аналіз технологій анаеробного бродіння на основі законів природи 3 оцінкою перспектив використання вторинних енергетичних ресурсів.

Викладення основних результатів дослідження. Технологї стабілізації осмотичних тисків. 3 порівнянь осмотичних тисків у зброджуваних середовищах випливає, що головним їх чинником є розчинений етиловий спирт, стабілізація концентрації якого на нижчому за критичний рівень дала б змогу реалізувати нові технології. Саме 3 цієї точки зору заслуговує на увагу досвід, накопичений у виробництві безалкогольного пива, який стосується методів видалення спирту 3 пива [2]. До останніх відносяться метод виготовлення льодяного пива (Eisbeer), технології з використанням осмосу і зворотного осмосу, принципу діалізу, термічні способи видалення спирту (дистиляція), вакуумні технології перегонки та відцентрові механічні випаровувачі.

Фізичне підгрунтя методу льодяного пива - це температурна депресія розчинів, яка $\epsilon$ наслідком розчинених екстрактивних речовин і спирту. Так, за екстрактивності початкового сусла $11,5 \%$ і вмісту спирту $4,6 \%$ об. температура замерзання становить $-2,3^{\circ} \mathrm{C}$, а за екстрактивності $15,5 \%$ і вмісту спирту $6,0 \%$ об. вона знижується до $-2,9^{\circ} \mathrm{C}$. Здійснення фазового переходу відбувається не гомогенно, а спочатку вимерзає вода. Разом з водою в лід виділяються нерозчинні за низьких температур поліфеноли і білки, а спирт збагачується іншими екстрактивними речовинами. Відокремлення твердої фази призводить до вилучення 3 неї спирту. В промислових умовах процес ведуть 3 постійним рухом середовища з утворенням кристалів рідинної фази $\mathrm{i}$ подальшим відокремленням.

У мембранних методах розділення пиво пропускають через напівпроникні мембрани, користуючись різними фізичними ефектами. Принцип зниження концентрації спирту реалізується на основі зворотного осмосу, за якого вода i спирт проходять через мембрану в напрямку проти природного осмотичного тиску, а втрати води компенсуються на основі знесоленої і деаерованої води.

При діалізі використовують мембрани у формі порожнистих волокон 3 обмеженою товщиною стінок. Такі волокна діаметром 50...200 мкм виконані 3 мікропорами 3 ущільненням 3 двох сторін супертонкими мембранами, через які проходить пиво, тоді як діалізат обтікає волокна в зворотному напрямку. Через мікропори мембран відбувається масообмін і речовини по обидва боки мембран, врешті-решт, досягають рівноважного стану за однакових концентрацій спирту.

Технології вилучення спирту з пива в промислових масштабах успішно реалізуються, проте вони стосуються тільки одержання безалкогольного пива, тоді як використання пермеату і діалізату залишається незавершеним.

Більш повноцінний результат досягається за використання термічних способів видалення спирту, оскільки при цьому досягається можливість концентрування і використання його розчинів. За таких умов досягається стабілізація концентрації $\mathrm{C}_{2} \mathrm{H}_{5} \mathrm{OH}$ в зброджуваному середовищі $\mathrm{i}$, одночасно, зростає концентрація спирту у випарі. Оскільки температура кипіння і випаровування визначається тиском, то зниження останнього до $0,04 \ldots 0,20$ бар призводить до поліпшення фізичних і термодинамічних умов видалення спирту. За вказа- 
них тисків температури кипіння можливо утримати в межах $30 \ldots 38^{\circ} \mathrm{C}$, що не має негативного впливу на мікроорганізми. Саме останнє дає змогу рекомендувати вакуум-випарні установки до застосування в спиртовій промисловості.

Одна 3 останніх розробок стосується відцентрових випаровувачів 3 внутрішніми поверхнями нагрівання тарілок. Під дією відцентрових сил пиво у тонкому шарі протікає між тарілок, нагрівається з випаровуванням спирту, тоді як пиво витискається назовні з обмеженою концентрацією алкоголю.

Результатом використання названих технологій є обмеження концентрацій алкоголю в кінцевому продукті близько $0,5 \%$. Водночас у технологіях виробництва спирту основне завдання щодо процесів бродіння $\epsilon$ принципово протилежним, оскільки накопичення $\mathrm{C}_{2} \mathrm{H}_{5} \mathrm{OH}$ в бражці повинно бути максимально можливим. Однак природні властивості дріжджів-цукроміцетів ставлять на цьому напрямку поки що нездоланну перепону, тому що найбільш досяжними в сучасних технологіях концентраціями спирту є показники $10 \ldots 12 \%$ об., які супроводжуються бактеріостатичними ефектами. Останній результат є добре вивченим у тисячолітніх накопиченнях і пошуках людства i стосовно технологій зброджування цукровмістких середовищ визначені їх переваги та негативи.

Головним позитивом анаеробного бродіння варто назвати ту обставину, що ця технологія абсолютно вписується в природні колообіги вуглецю, кисню і води, які в різних формах спричиняють утворення органічних з'єднаньносіїв хімічної енергії і заслуговують на назву акумуляторів сонячної енергії.

Первинний енергетичний потенціал цих трансформацій представлений глюкозою, з подальшими перетвореннями в полімерні органічні сполуки, жири, білки і вуглеводи. Один із важливих напрямків у таких перетвореннях стосується анаеробних процесів бродіння.

Перебіг будь-якого процесу потребує відповідного енергоматеріального забезпечення на користь рушійного фактора. Енергетична "вартість" трансформації одного моля глюкози в дві молекули етилового спирту і дві молекули діоксиду вуглецю складає ту енергію, яка збереглася у формі двох молекул АТФ у кількості $2 \cdot 30,5=61$ кДж/моль глюкози. Разом 3 тим втрата енергетичного потенціалу в трансформації від моля глюкози до моля спирту становить:

$$
\delta Q=2870-2640=230 \text { кДж/моль глюкози. }
$$

Хоча втрата енергетичного потенціалу складає лише $8 \%$ від початкового потенціалу, вона в масовому виробництві і в абсолютних показниках $\epsilon$ вагомим недоліком процесів бродіння. Важливо, що цей недолік доповнюється необхідністю компенсувати залишок виділеної вільної енергії у кількості

$$
230-61=169 \text { кДж/моль глюкози }
$$

влаштуванням системи охолодження бродильного апарата і відповідними енергоматеріальними втратами.

Повернувшись до наслідків процесів анаеробного бродіння, підкреслимо, що насичення рідинної фази діоксидом вуглецю у своїй кількісній характеристиці обмежується відповідно до закону Генрі. Однак хоча таке обмеження стосується і осмотичного тиску розчиненого $\mathrm{CO}_{2}$, існує ще одна перепона 
масообміну на поверхні поділу фаз «середовище-мікроорганізми». Стан насичення рідинної фази $\mathrm{CO}_{2}$ ускладнює звільнення клітин від синтезованого в них газу, тоді як розчинність спирту обмежень не має. Зменшення і стабілізація концентрацій спирту в середовищах можлива, наприклад, за рахунок часткової перегонки за знижених тисків, в якій використовується біологічна теплота бродіння. При цьому синтезованої в $1 \mathrm{~m}^{3}$ середовища теплової енергії $Q$ за теплоти пароутворення спирту $r_{\text {сп }}=910,9$ кДж/кг повинно вистачити для одержання $\mathrm{C}_{2} \mathrm{H}_{5} \mathrm{OH}$ в теоретичному підрахунку у кількості 165 кг, що майже вдвічі перевищує вихід спирту.

Названі енергоматеріальні співвідношення приводять до висновку про можливість здійснення повного процесу перегонки за рахунок трансформованої теплоти бродіння з використанням теплових трансформаторів. За таких умов класична схема оформлення процесів бродіння і перегонки має доповнюватися тепловим насосом, за допомогою якого низькопотенціальний потік теплоти бродіння трансформується в потік більш високого температурного потенціалу. Саме така роль теплового насоса дає змогу подолати бар'єр першого закону термодинаміки, за яким передавання теплового потоку можливе тільки від більш нагрітого середовища до менш нагрітого. У зв'язку з цим підвищення енергетичного потенціалу теплоти бродіння потребує зовнішньої енергії того ж або іншого виду: електричної, механічної, хімічної, кінетичної енергії потоку пари або газу. Робота теплонасосних установок потребує підвищення тиску робочого тіла, який досягається за рахунок компресійних, сорбційних та струменевих явищ.

Робота компресійних установок заснована на підвищенні тиску газу або пари шляхом механічної або термодинамічної дії, що приводить до збільшення їх температури. При цьому таке збільшення в абсолютному значенні має перевищувати температуру більш нагрітого середовища.

Робота сорбційних установок грунтується на підвищенні тиску робочого агента за рахунок послідовного здійснення термохімічних реакцій поглинання речовини відповідним сорбентом з відведенням теплоти, а потім виділення десорбції робочої речовини із сорбенту, що супроводжується підведенням теплоти.

Струменеві термотрансформатори працюють за рахунок кінетичної енергії потоку пари або газу з підвищенням тиску робочого агента. Високошвидкісні струмені потоків пари або газу в ежекційних апаратах створюють всмоктування, а потім стискання середовища робочого тіла. Струменеві установки виконуються як закритими, так і відкритими термодинамічними системами. В закритих системах робочий агент виконує перетворення термодинамічного тиску, а у відкритих системах процес розімкнений.

3 урахуванням особливостей роботи бродильних апаратів і процесів перегонки доцільно рекомендувати до використання турбокомпресорні системи. В першому наближенні ідеальний цикл такої установки можливо вважати відповідним до зворотного циклу Карно. Ефективність роботи теплового насоса $\varphi$ визначається відношенням теплоти $Q_{\kappa}$, що віддає конденсатор, до роботи стискання компресора $L$ : 


$$
\varphi_{\text {теор. }}=\frac{Q_{\kappa}}{L}=\frac{T_{0}}{T_{1}-T_{0}},
$$

де $T_{0}-$ температура випаровування; $T_{1}-$ температура конденсації робочого агента.

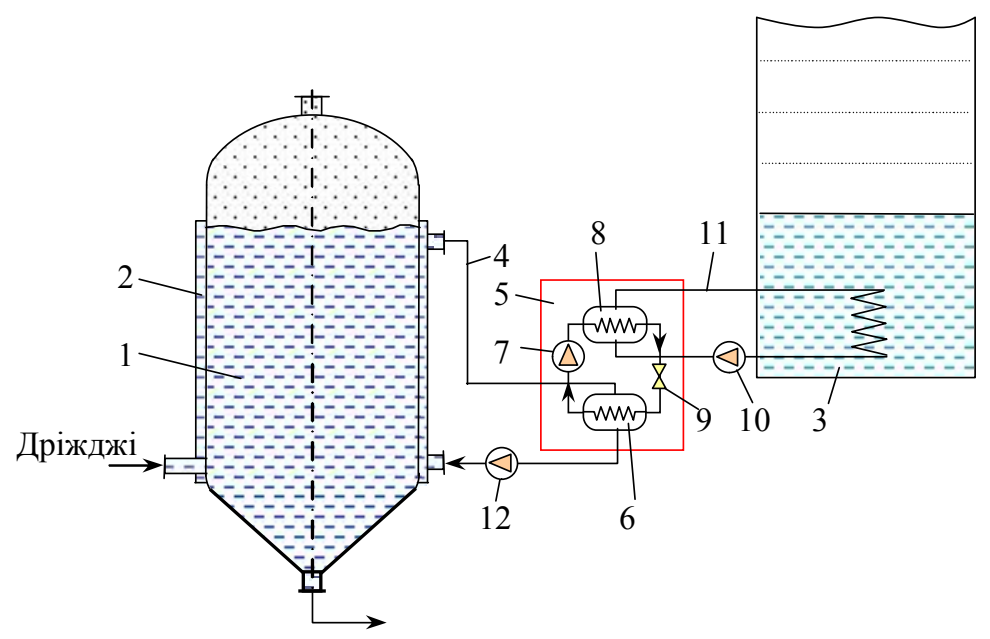

Рис. 1. Система зброджування і перегонки сусла у виробництві етанолу (патент України № 124096)

Відповідно до останньої умови ефективність теплового насоса залежить від різниці температур $T_{1}$ та $T_{2}$ і в промислових зразках досягаються значення $\varphi=5 \ldots 10$ одиниць.

До використання пропонується система зброджування і перегонки сусла у виробництві етанолу [6] (рис. 1), яка складається з бродильного апарата 13 сорочкою охолодження 2, брагоперегонної колони 3 , контуру 4 охолодження бродильного апарата, теплового насоса 5 у складі випарника 6, компресора 7 , конденсатора 8, регулювального вентиля 9 та насосів 10, контуру 11 нагрівання брагоперегонної колони.

Працює запропонована система таким чином: теплота зброджування відводиться від зброджуваного середовища за рахунок сорочки охолодження, стабілізуючи температуру на номінальному значенні. Технічне забезпечення цього процесу передбачає охолодження робочого агента контуру 4 у випарнику 6 теплового насоса.

Замкнутий контур 4 забезпечує циклічний процес, в якому відповідно до першого і другого законів термодинаміки відбуються процеси нагрівання й охолодження з температурно-тепловою циркуляцією, підсиленою насосом 12. За вказаних умов замкнутий контур ліквідує втрати робочого агента, роль якого може виконувати вода. Окрім того, нівелюється термодинамічний недолік відкритих систем теплообміну, пов'язаний зі збільшенням внутрішніх енергетичних втрат через кінцеву різницю температур теплоносіїв і досягається можливість регулювання перепадів температур у випарнику як 
рушійного фактора теплопередачі. Утворювана у випарнику парова фаза енергоносія теплового насоса стискається компресором 7 з підвищенням його температури до $105 \ldots 110^{\circ} \mathrm{C}$ і передається в конденсатор 8 , де конденсується 3 передаванням теплового потоку в контур нагрівання брагоперегонної колони 11. Сконденсований теплоносій теплового насоса в регулювальному вентилі трансформується зі зниженням тиску і температури та повертається до випарника 3 подальшими перетвореннями в циклі. Контур 11 нагрівання середовища брагоперегонної колони забезпечує утворення в ній пароспиртової суміші і роботу колони в режимі перегонки. Результатом такої трансформації низькопотенціального потоку теплоти бродіння, яка в сучасних схемах супроводжується додатковими енергоматеріальними витратами, $є$ повноцінна рекуперація вторинних енергетичних ресурсів 3 використанням подвійних можливостей теплових насосів одержувати вихідні потоки для термостабілізації охолодженням зброджуваних середовищ і для теплоенергетичного забезпечення процесів перегонки. Названі переваги відкривають перспективи використання теплових насосів у таких системах, хоча до термодинамічних недоліків слід віднести наявність у запропонованій системі чотирьох поверхонь теплопередачі і процесу розширення холодильного агента в дроселі.

При цьому мають місце втрати тиску за рахунок механічного тертя. Хоча у процесі розширення робочого агента ніяка робота не відбувається і дросель не впливає на кількість теплоти, отриманої в конденсаторі, однак зменшується кількість теплоти, що сприймається у випаровувачі при сталій температурі. В результаті взаємодія потоку холодильного агента 3 дроселем робить процес незворотним і ця особливість виключенню не підлягає. Разом з тим існує можливість обмеження кількості поверхонь теплопередачі за збереження ідеї використання теплового насоса для трансформації низькопотенціального потоку у високопотенціальний (рис. 2). Система енергетичного забезпечення термостабілізації зброджуваного середовища і процесу перегонки на термодинамічних основах теплових насосів складається з бродильного апарата 13 сорочкою охолодження 2 , бражної колони 3 з сорочкою нагрівання 4 , компресора $\mathbf{5}$, дроселя 6 і гідравлічного акумулятора 7, трубопроводів 8. Сорочки нагрівання і охолодження, компресор, дросель і трубопроводи складають циркуляційний контур, заповнений робочим агентом, а гідравлічний акумулятор забезпечує підтримання заданого рівня останнього.

Робота системи відбувається таким чином: циркуляційний контур заповнюється робочим агентом і після досягнення середовищем температури номінального значення починається випаровування робочого агента в сорочці охолодження бродильного апарата. Наявність фазового переходу в цьому теплообмінному процесі означає його оптимізацію за показником коефіцієнта тепловіддачі $\alpha_{2}$, здійснюється стискання утвореної газової фази, температура якої підвищується до $110 \ldots 120^{\circ} \mathrm{C}$ і передається в сорочку нагрівання брагоперегонної колони. В процесі конденсації робочого агента досягається екстремальне значення коефіцієнта тепловіддачі $\alpha_{1}$ на користь передачі теплового потоку кубовій рідинній фазі. При цьому незворотний характер процесів термодина- 
мічних перетворень компенсується роботою компресора, який забезпечує існування циклу з відповідними параметрами тисків і температур.

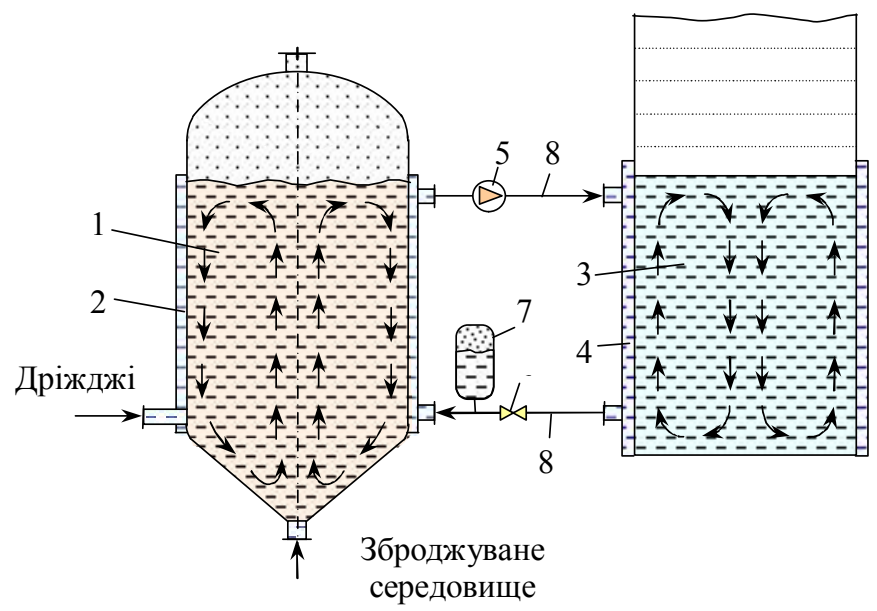

Рис. 2. Система енергетичного забезпечення термостабілізації зброджуваного середовища і процесу перегонки етилового спирту на термодинамічних основах теплових насосів

До використання пропонується спосіб зброджування цукровмісних середовищ (патент України № 124158) [7]. В основу пропозиції поставлене завдання обмеження впливу на ендогенний синтез спирту і діоксиду вуглецю за рахунок дискретних ліквідацій станів насичення середовищ діоксидом вуглецю, підвищення зброджувальної активності дріжджів, продуктивності, концентрації етилового спирту та зменшення енергетичних витрат на процес перегонки.

Самогенерування діоксиду вуглецю в процесах бродіння супроводжується його масопередачею на межі поділу фаз «дріжджові клітини - середовище» i поступовим підвищенням його концентрації до рівня насичення. Відповідно до закону Генрі, за яким константа насичення пропорційна парціальному тиску газової фази, середовище можливо переводити 3 насиченого стану в ненасичений i, навпаки, за рахунок зміни тиску в середовищі, наприклад, зміною тиску в газовому надрідинному об'ємі. Зменшення тиску в системі зменшує розчинність газу і переводить середовище в перенасичений стан, завдяки якому активно відбувається його дегазація.

Наступне підвищення тиску в системі приводить середовище в ненасичений стан 3 активізацією масопередачі на межі поділу фаз, підвищується зброджувальна активність дріжджів, зростають продуктивність, концентрація етилового спирту і зменшуються енергетичні витрати на процес перегонки.

Реалізація вказаного способу може бути здійснена на основі патенту України 124159 [8].

Для досягнення інтенсивних процесів до використання пропонується система зброджування сусла у виробництві етанолу [8] (рис. 3), яка складається з бродильного апарата 1 з сорочкою термостабілізації 2 та замкнутого 
контуру змінних регульованих тисків у складі контролера $\mathbf{3}$, компресора 4, ресивера 5, датчика тиску 6, трубопроводів 7, запірних клапанів 8 і 9 та запобіжного клапана 10.

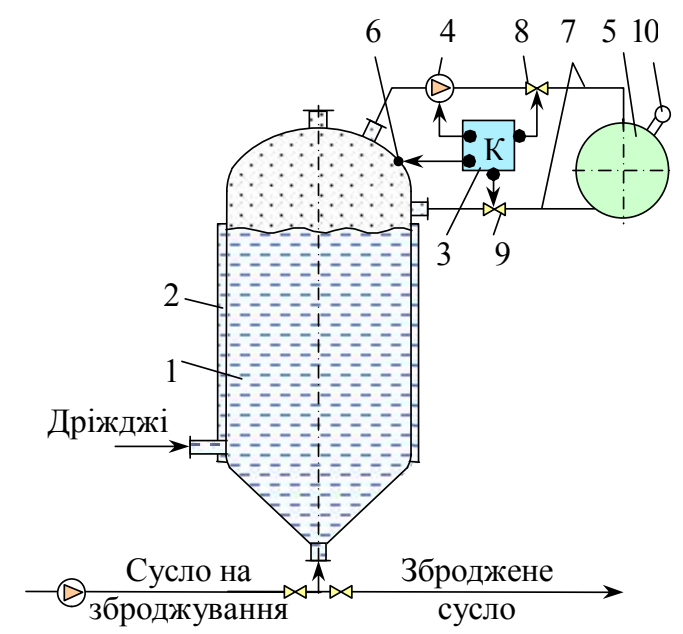

Рис. 3. Система зброджування сусла у виробництві етанолу (патент України № 124 159)

Працює система у такий спосіб: середовище надходить у бродильний апарат 1 з сорочкою термостабілізації 2, і разом 3 ним на складку подаються дріжджі. Від початку бродіння утворюваний $\mathrm{CO}_{2}$ підвищує концентрацію в рідинній фазі середовища до стану насичення, показник якого залежить від тиску в надрідинному об'ємі апарата і від гідростатичного тиску. У зв'язку 3 впливом останнього в середовищі утворюється концентраційний по $\mathrm{CO}_{2}$ градієнт і розпочинається за досягнення стану насичення заповнення надрідинного об'єму діоксидом вуглецю з досягненням максимального тиску, який контролюється запобіжним клапаном 10 при відкритих клапанах 8 i 9 на трубопроводі 7. Досягнення максимального тиску газової фази означає наявність максимальних показників насичення середовища на $\mathrm{CO}_{2}$, за яких настають обмеження процесів переходу його 3 клітин до середовища. За сигналом датчика тиску 6 і відповідною командою контролера 3 закривається клапан 9 і вмикається компресор 4, тиск у газовому об'ємі апарата знижується, а в ресивері 5 підвищується. Зниження тиску в надрідинному об'ємі супроводжується еквівалентним зниженням тиску у повному об'ємі рідинної фази, в результаті чого середовище переходить у перенасичений стан 3 активним виділенням $\mathrm{CO}_{2}$ у формі бульбашок диспергованої газової фази. При цьому середовище продовжує залишатися в перенасиченому стані. Після досягнення мінімального програмованого тиску в надрідинному об'ємі бродильного апарата за командою контролера вимикається компресор 4, закривається запірний клапан 8 і витримується короткочасна пауза щодо тисків. Після іiі завершення контролер видає команду на різке відкривання клапана 9 і газова фаза 3 ресивера швидкоплинно розповсюджується на весь об'єм системи. 
Зростання тиску над середовищем викликає колапс пінної фракції і створює аналог кавітації щодо диспергованої газової фази. Підвищений тиск переводить рідинну фазу середовища в ненасичений стан по $\mathrm{CO}_{2}$, що активізує процес бродіння $з$ відповідними наслідками. Надлишковий тиск $\mathrm{CO}_{2}$ у системі регулюється запобіжним клапаном 10. Після нового зростання тиску в системі цикл повторюється.

\section{Висновки}

Виконаний феноменологічний аналіз особливостей процесів анаеробного зброджування цукровмісних середовищ дає змогу зробити такі висновки:

1. До числа важливих чинників, які впливають на динаміку процесів бродіння і на їх кінцевий результат за показником концентрації цільової речовини, відносяться осмотичні тиски розчинів $\mathrm{CO}_{2} \mathrm{i}_{2} \mathrm{H}_{5} \mathrm{OH} 3$ особливими режимами впливів. Останне пов'язано з їх різними граничними розчинностями в рідинній фазі середовища, оскільки етиловий спирт з водними розчинами таких обмежень не має, на відміну від $\mathrm{CO}_{2}$.

2. Максимальні осмотичні тиски розчинів $\mathrm{CO}_{2}$ виникають в обмеженому часі бродіння у зв'язку з досягненням рівня насичення відповідно до закону Генрі. Після цього вони залишаються на посередньому рівні на фоні постійно зростаючих рівнів концентрації й осмотичного тиску $\mathrm{C}_{2} \mathrm{H}_{5} \mathrm{OH}$.

3. Важливою складовою у формі впливу на розчинність $\mathrm{CO}_{2}$ (а отже, i на осмотичний тиску від його розчину) виступають гідростатичні тиски. За гіпотезою авторів поєднання гідростатичних тисків і систем охолодження бродильних апаратів відіграють важливу роль у формуванні дисперсної газової фази на основі існування циркуляційних контурів. Завдяки останнім у середовищах утворюються локальні зони, перенасичені на $\mathrm{CO}_{2}$ i ненасичені. Перенасичені зони (або зони десатурації) відповідають висхідним потокам циркуляційних контурів, а опускним потокам, наближеним до поверхонь охолодження, - ненасичені зони (зони сатурації). Існування таких зон відповідає самопливним процесам.

4. Завдяки законам розчинності газів у рідинних середовищах виникає можливість штучного переведення останніх в режими насичених і ненасичених на $\mathrm{CO}_{2}$ станів на основі змінних тисків над газорідинними середовищами. Це дає змогу досягати позитивних впливів у двох напрямках, а саме: регульованих впливів на загальний рівень осмотичних тисків і на опір масопередачі $\mathrm{CO}_{2}$ від дріжджових клітин до середовища. Одночасно з цим зміни тисків над середовищем приводять до інтенсифікації масообмінних процесів.

5. Обмеження осмотичних тисків від етилового спирту можливі лише за рахунок зниження його концентрацій, через це варто поєднувати в одному режимі процесів синтезу спирту 3 процесом перегонки. У зв'язку 3 обмеженням максимальної температури середовища значеннями $30 \ldots 32^{\circ} \mathrm{C}$ середовище повинно бути під тиском 0,475 м в. ст. Однак технічна реалізація таких умов практично неможлива через гідростатичні тиски в сучасних бродильних апаратах. Уникнути негативних впливів гідростатичних тисків можливо шляхом використання окремих вакуумованих камер в режим вільного падіння середовищ. 
6. Технологічні прийоми зниження концентрацій спирту у виробництві безалкогольного пива перспектив застосування у спиртовій галузі не мають. Разом 3 тим створення штучних газорідинних контурів на основі рециркуляції $\mathrm{CO}_{2}$ забезпечує збільшення рівня вилучення спирту у вихідній газовій фазі, яка має спрямовуватися на конденсатори-спиртовловлювачі.

7. Утилізація теплоти бродіння можлива в паралельних процесах зброджування середовищ і перегонки за умови використання проміжного енергоносія в складі теплового насоса.

\section{Література}

1. Енергоматеріальні трансформації в бродильних технологіях / Шевченко О.Ю. та ін. // Наукові праці Національного університету харчових технологій. —2017. — Том 23, № 4. C. $89-98$.

2. Куние B. Технология солода и пива. - Санкт-Петербург : Профессия, 2001. - 326 с.

3. Особливості трансформацій матеріальних і енергетичних потоків у бродильних середовищах / Шевченко О.Ю. та ін. // Наукові праці Національного університету харчових технологій. -2017.- Том 23, № 3. - С. 107-115.

4. Енергетичні потенціали газорідинних середовищ / Соколенко А. І. та ін. // Наукові праці Національного університету харчових технологій. - 2018. - Том 24, № 1. C. $108-118$.

5. Динаміка перехідних процесів у системах анаеробного бродіння / Шевченко О. Ю. // Наукові праці Національного університету харчових технологій. — 2017. — Том 23, № 6. C. $68-76$.

6. Система зброджування і перегонки сусла у виробництві етанолу: патент на корисну модель 124096 Україна: МПК C12G 3/10 (2006.01), B01D 3/10 (2006.01), C12C 7/22 (2006.01) / Шевченко О.Ю., Соколенко А.І., Васильківський К.В., Максименко І.Ф., Вінніченко І.М.; власник НУХТ. № u201708590; заявл. 22.08.2017; опубл. 26.03.2018, Бюл. № 6.

7. Спосіб зброджування цукровмісних середовищ: патент на корисну модель 124158 Україна: C12F 3/08 (2006.01), C12G 3/02 (2006.01) / Соколенко А.І., Шевченко О.Ю., Максименко І.Ф., Степанець О.І., Вінніченко І.М.; власник НУХТ. № u201709858; заявл. 11.10.2017; опубл. 26.03.2018, Бюл. № 6.

8. Система зброджування сусла у виробництві етанолу: патент на корисну модель 124159 Україна: C12G 3/10 (2006.01), C12P 7/06 (2006.01) / Шевченко О.Ю., Соколенко А.І., Степанець О.І., Максименко І.Ф.; власник НУХТ. № u201709860; заявл. 11.10.2017; опубл. 26.03.2018, Бюл. № 6. 